\title{
Mode of action of an antialgal agent produced by a marine gammaproteobacterium against Chattonella marina
}

\author{
Takuji Nakashima ${ }^{1,3, *}$, Daekyung Kim ${ }^{1}$, Yousuke Miyazaki ${ }^{1}$, Kenichi Yamaguchi ${ }^{1}$, \\ Satoshi Takeshita ${ }^{2}$, Tatsuya Oda ${ }^{1}$ \\ ${ }^{1}$ Division of Biochemistry, Faculty of Fisheries, Nagasaki University, Nagasaki 852-8521, Japan \\ ${ }^{2}$ Joint Research Center, Nagasaki University, Nagasaki 852-8521, Japan \\ ${ }^{3}$ Present address: NITE Biological Resource Center (NBRC), National Institute of Technology and Evaluation (NITE), \\ Chiba 292-0812, Japan
}

\begin{abstract}
A marine gammaproteobacterium, strain MS-02-063, was able to kill Chattonella marina, a noxious red tide phytoplankton. However, the algicidal activity of bacterial cells washed with the planktonic medium was significantly reduced. These results suggest that strain MS-02-063 produces an extracellular substance, the pigment, PG-L-1, that showed a potent algicidal effect on $C$. marina. The $\mathrm{LD}_{50}$ value of PG-L-1 was calculated to be approximately $8.5 \mu \mathrm{g} \mathrm{ml}^{-1}$. At the approximate $\mathrm{LD}_{50}$ concentration of $10 \mu \mathrm{g} \mathrm{ml}^{-1}$, a morphological change, which seemed to be due to the inhibition of cell division, was observed in C. marina. Almost all cells of $C$. marina were destroyed readily at $100 \mathrm{\mu g} \mathrm{ml}^{-1}$ of PG-L-1, and the cytostatic activity of PG-L-1 against this phytoplankton was observed at a concentration of $1 \mu \mathrm{g} \mathrm{ml}^{-1}$ during the $5 \mathrm{~d}$ of incubation. A sublethal concentration of PG-L-1 of $10 \mu \mathrm{g} \mathrm{ml}^{-1}$ significantly inhibited the reactive oxygen species (ROS) production by C. marina. ROS production has been previously reported to be essential for normal growth of C. marina (Oda et al. 1995; Biosci Biotechnol Biochem 59:2044-2048). Therefore, the inhibitory effect of PG-L-1 on ROS production may lead to growth inhibition of C. marina, at least in part. The pigment, PG-L-1, may be a useful compound not only as an applicable agent for the mitigation of harmful algal blooms, but also as an experimental tool to analyse the ROS production system in a red tide phytoplankton such as C. marina.
\end{abstract}

KEY WORDS: Prodigiosin · Algicidal activity - Gammaproteobacterium · Red tide phytoplankton · Chattonella marina $\cdot$ Reactive oxygen species

Resale or republication not permitted without written consent of the publisher

\section{INTRODUCTION}

Harmful algal blooms (HABs) due to flagellated algae such as Chattonella marina (Raphidophyceae) are associated with the mass mortality of natural marine living organisms and have frequently caused serious damage to the aquaculture industry (Landsberg 2002). Several lines of evidence suggest that marine bacteria play an important role in regulating microalgal biomass in natural marine environments (Furuki \& Kobayashi 1991, Imai et al. 2001, Iwata et al. 2004). Some marine bacteria selectively promote bloom formations by certain algal species (Furuki \& Kobayashi 1991), whereas other bacteria have algicidal effects, and they even cause the termination and decomposition of algal blooms (Imai et al. 2001, Iwata et al. 2004). The latter findings have raised the possibility of bacterial control of HABs, and the algicidal bacteria have been considered as useful tools to reduce the impacts of HABs. The underlying algicidal mechanisms seem to be dependent on the species of bacteria, and 2 modes of algicidal activity depending on the bacterial species have been proposed. Some bacteria have been reported to affect red tide phytoplankton through direct cell-to-cell contact (Imai et al. 1993). On the other hand, certain bacteria are known to release extracellular compounds that affect the growth of red tide phytoplankton (Lovejoy et al. 1998, Seong-Yun et al. 2003). 
During our screening of useful bacteria that produce anti-microbial agents from the coastal area of Nagasaki, Japan, we discovered a red-pigmented bacterium, designated as strain MS-02-063. Strain MS02-063 was phylogenetically closely related to gammaproteobacterium MBIC 3957; however, there were differences in the physiological and biochemical properties (Nakashima et al. 2005b). The red pigment produced by strain MS-02-063 had potent antifungal, antibacterial, and in vitro antitumor activities (Nakashima et al. 2005a, 2005b, 2005c). Our chemical structural and biochemical analysis revealed that this red pigment belongs to the prodigiosin family, and we named it PG-L-1. Other marine bacteria such as Pseudoalteromonas bacteriolytica and Vibrio ruber also produce prodigiosin-like pigments (Sawabe et al. 1998, Shieh et al. 2003). We found that PG-L-1, a prodigiosin analogue pigment, shows potent algicidal activity against several red tide phytoplankton (Nakashima et al. 2006) and, therefore, conducted a detailed analysis of the algicidal mechanism of PG-L-1 in Chattonella marina. To search for new aspects of biochemical activity of PG-L-1 against C. marina, we also examined the effect of PG-L-1 on reactive oxygen species (ROS) production by $C$ marina, which is essential for the growth of this red tide phytoplankton.

\section{MATERIALS AND METHODS}

Bacteria strains and growth conditions. A marine bacterium, strain MS-02-063, was isolated from the coastal area of Omura Bay, Nagasaki, Japan (Nakashima et al. 2005b). The bacterial clone was cultured at $28^{\circ} \mathrm{C}$ for $40 \mathrm{~h}$, with shaking, in a medium composed of $12.5 \mathrm{~g}$ yeast extract (Becton Dickinson), $12.5 \mathrm{~g}$ peptone (Becton Dickinson), and $30 \mathrm{~g}_{\text {glucose }} \mathrm{l}^{-1}$ of $50 \%$ artificial seawater. Since strain MS-02-063 is a slime bacterium, the method of viable bacterial cell counts on nutrient agar was unsuitable; therefore, the bacterial DNA was stained with the dye, 4,6-diamidino 2phenylindole dihydrochloride (DAPI; Sigma-Aldrich), and total cell number was determined as described by Porter \& Feig (1980).

Red tide phytoplankton. Chattonella marina was generously provided by Kagoshima Prefectural Fisheries Experimental Station, Japan. An axenic culture of this algal strain was maintained at $26^{\circ} \mathrm{C}$ in ErdSchreiber modified (ESM) medium $(\mathrm{pH}$ 8.2) under illumination from a fluorescent lamp (30 $\mu$ mol photons $\mathrm{m}^{-2} \mathrm{~s}^{-1}$ ) with a cycle of $12 \mathrm{~h}$ light and $12 \mathrm{~h}$ dark.

Preparation of PG-L-1. Pigment PG-L-1 produced by strain MS-02-063 was purified as described in Nakashima et al. (2005b). The maximal PG-L-1 production was achieved by incubation for $40 \mathrm{~h}$ at $28^{\circ} \mathrm{C}$
(Nakashima et al. 2006). The PG-L-1 was dissolved in methanol at a concentration of $10 \mathrm{mg} \mathrm{ml}^{-1}$ and stored in the dark at $-20^{\circ} \mathrm{C}$ until use.

Mixed algal-bacterial cultures. Effects of strain MS02-063 on Chattonella marina were examined by mixed algal-bacterial cultures. C. marina in logarithmic growth phase and strain MS-02-063 that was at the maximal PG-L-1 production (cultivation for $40 \mathrm{~h}$ ) were diluted with ESM medium to densities of $2 \times 10^{4}$ and $2 \times 10^{7}$ cells $\mathrm{ml}^{-1}$, respectively. Subsequently, strain MS-02-063 was added into ESM medium in serial 10fold dilutions at bacterial cell densities ranging from 0 to $2 \times 10^{7}$ cells $\mathrm{ml}^{-1}$. Aliquots $(500 \mu \mathrm{l})$ of the strain MS02-063 and C. marina cell suspension were dispensed in the wells of 24-well plates and then incubated at $26^{\circ} \mathrm{C}$ under light illumination at $30 \mu \mathrm{mol}$ photons $\mathrm{m}^{-2}$ $\mathrm{s}^{-1}$ with a cycle of $12 \mathrm{~h}$ light and $12 \mathrm{~h}$ dark. After incubation for $24 \mathrm{~h}$, the number of viable algal cells that were not lysed was determined with a haemacytometer at a magnification of $\times 100$.

Algicidal effect of strain MS-02-063 on Chattonella marina. To test the algicidal effect of strain MS-02-063 on C. marina through direct cell-to-cell contact, the bacterial cells were harvested by centrifugation $(10000 \times g$ for $10 \mathrm{~min})$, and the pellet was vigorously washed 3 times with ESM medium. The washed bacterial cells were resuspended in ESM medium to a density of $2 \times 10^{5}$ cells $\mathrm{ml}^{-1}$. The algicidal activity of washed bacterial cells was measured using a haemacytometer at a magnification of $\times 100$.

Algicidal effect of PG-L-1 on Chattonella marina. To elucidate the algicidal activity of PG-L-1, 2 experiments that differed in exposure times of C. marina to PG-L-1 were performed. The stock solution of PG-L-1 was diluted 50-fold in ESM medium, and serial 2-fold dilutions in ESM medium were prepared. C. marina in the logarithmic growth phase was diluted in ESM medium to a final density of $1 \times 10^{4}$ cells ml ${ }^{-1}$ for a short exposure time or to $1 \times 10^{3}$ cells $\mathrm{ml}^{-1}$ for a long exposure time. Aliquots $(500 \mu \mathrm{l})$ of PG-L-1 in ESM medium and the $C$. marina cell suspension were dispensed into the wells of 24-well plates. The final concentrations of PG-L-1 ranged from 100 to $0.1 \mu \mathrm{g} \mathrm{ml}^{-1}$. After 1,3 , and $6 \mathrm{~h}$ or 1 , $2,3,4$, and $5 \mathrm{~d}$ of incubation, the algicidal activity of PG-L-1 was measured using a haemacytometer at a magnification of $\times 100$.

Morphological change in Chattonella marina. PG-L-1, at a final concentration of $10 \mu \mathrm{g} \mathrm{ml} \mathrm{m}^{-1}$, was added to the cell suspensions of $C$. marina $\left(1 \times 10^{4}\right.$ cells $\mathrm{ml}^{-1}$ ) in the wells of a 12 -well plate. The plates were incubated at $26^{\circ} \mathrm{C}$ for $24 \mathrm{~h}$ under the growth conditions described previously. After incubation, the C. marina cells treated with PG-L-1 were observed at a magnification of $400 \times$ using a Axiovent 200 Microscope (Carl Zeiss). 
Chemiluminescence assay for detection of ROS. In the chemiluminescence analysis for the detection of ROS produced by Chattonella marina, we employed L-012 (Wako Chemical), which is a highly sensitive chemiluminescence probe for analyzing ROS (Imada et al. 1999). The L-012 was dissolved in distilled water and stored at $-80^{\circ} \mathrm{C}$. An aliquot of various concentrations of PG-L-1 or superoxide dismutase (SOD) at a final concentration of $10 \mathrm{U} \mathrm{ml}^{-1}$ in ESM medium were added to $C$. marina cell suspensions (final cell density from $1.5 \times 10^{3}$ to $5 \times$ $10^{4}$ cells well ${ }^{-1}$ ) in wells of a 96 -well white microplate (Dynex MicroliteTM 1; Dynex Technologies). The final concentrations of PG-L-1 ranged from 10 to $0.1 \mu \mathrm{g} \mathrm{ml}^{-1}$. After incubation of the mixture for $30 \mathrm{~s}$ at $26^{\circ} \mathrm{C}$, the reaction was started by the addition of $10 \mu \mathrm{l}$ of L-012 solution (final concentration of $10 \mu \mathrm{M}$ ). During the incubation, chemiluminescence intensity of each well was recorded continuously for 2 min by using a multilabel recorder Mithras LB940 (Berthold Technologies).

Statistical analysis. Individual treatment groups were compared with appropriate controls using Dunnett's multiple comparison test. Data points were represented as triplicate means $\pm \mathrm{SD}$.

\section{RESULTS}

\section{Algicidal activity of strain MS-02-063 against Chattonella marina}

As shown in Fig. 1A, the suspension of strain MS-02063 inhibited the growth of Chattonella marina in a density-dependent manner. In the presence of $1 \times 10^{5}$ cells $\mathrm{ml}^{-1}$ of strain MS-02-063, almost all C. marina cells died within $24 \mathrm{~h}$. In contrast to the potent algicidal activity of the culture suspension, the algicidal activity against $C$. marina was significantly reduced in the bacterial cells that were vigorously washed with ESM medium (Fig. 1B).

\section{Algicidal activity of PG-L-1 against Chattonella marina}

As shown in Fig. 2, PG-L-1 had potent algicidal effects on Chattonella marina in a concentrationdependent manner. The $\mathrm{LD}_{50}$ value of PG-L-1 against C. marina was calculated to be approximately $8.5 \mu \mathrm{g}$ $\mathrm{ml}^{-1}$ from the dose-response curve.

\section{Morphological change in Chattonella marina}

Chattonella marina has no rigid cellular structure and the algal cells often undergo morphological
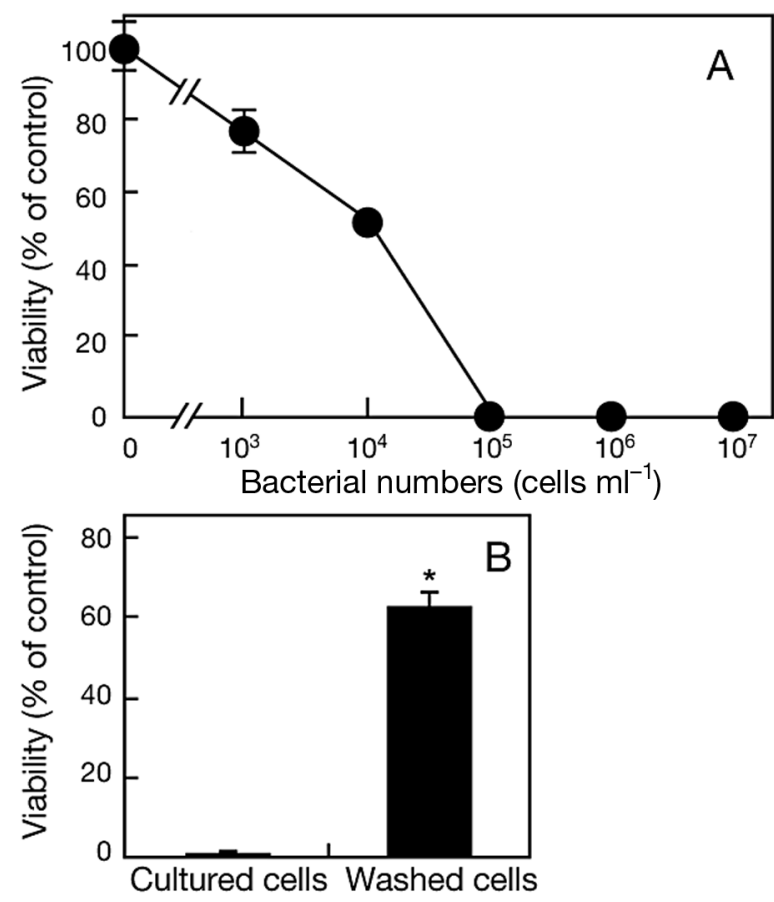

Fig. 1. Chattonella marina. Algicidal effect of strain MS-02063. (A) C. marina cell suspension $\left(1 \times 10^{4}\right.$ cells $\left.\mathrm{ml}^{-1}\right)$ in ESM (Erd-Schreiber modified) medium was mixed with various concentrations of strain MS-02-063 cells $\left(0\right.$ to $10^{7}$ cells ml $\left.{ }^{-1}\right)$. Then the mixtures were cultured under normal culture conditions as described in 'Materials and methods'. After incubation for $24 \mathrm{~h}$, the number of viable cells of $C$. marina were counted. (B) The bacterial cell suspension washed with ESM medium was added to $C$. marina cell suspension $\left(1 \times 10^{5}\right.$ cells $\mathrm{ml}^{-1}$ ). Non-washed bacteria cell suspension (cultured cells) was used as a positive control. After incubation for $24 \mathrm{~h}$ the number of viable cells of $C$. marina were counted. Experiments were performed in triplicate. Error bars represent SD. Significant differences between the groups of washed and non-washed bacteria cell suspensions are indicated by *: $p<0.01$

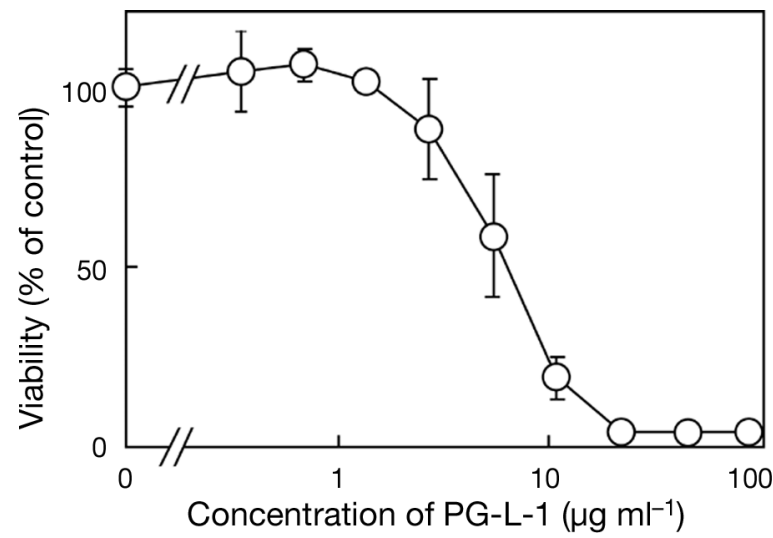

Fig. 2. Chattonella marina. Algicidal effect of PG-L-1. The indicated final concentrations of PG-L-1 were added to $C$. marina cell suspension $\left(1 \times 10^{4}\right.$ cells ml-1 $)$. After incubation for $24 \mathrm{~h}$, the number of viable cells of $C$. marina were counted. Experiments were performed in triplicate. Error bars represent SD 
changes under unfavorable culture conditions or when this alga is exposed to exogenous toxic stress. In agreement with these findings, PG-L-1 $\left(10 \mu \mathrm{g} \mathrm{ml}^{-1}\right)$ induced dramatic morphological changes in C. marina cells (Fig. 3B) that were easily distinguishable from normal
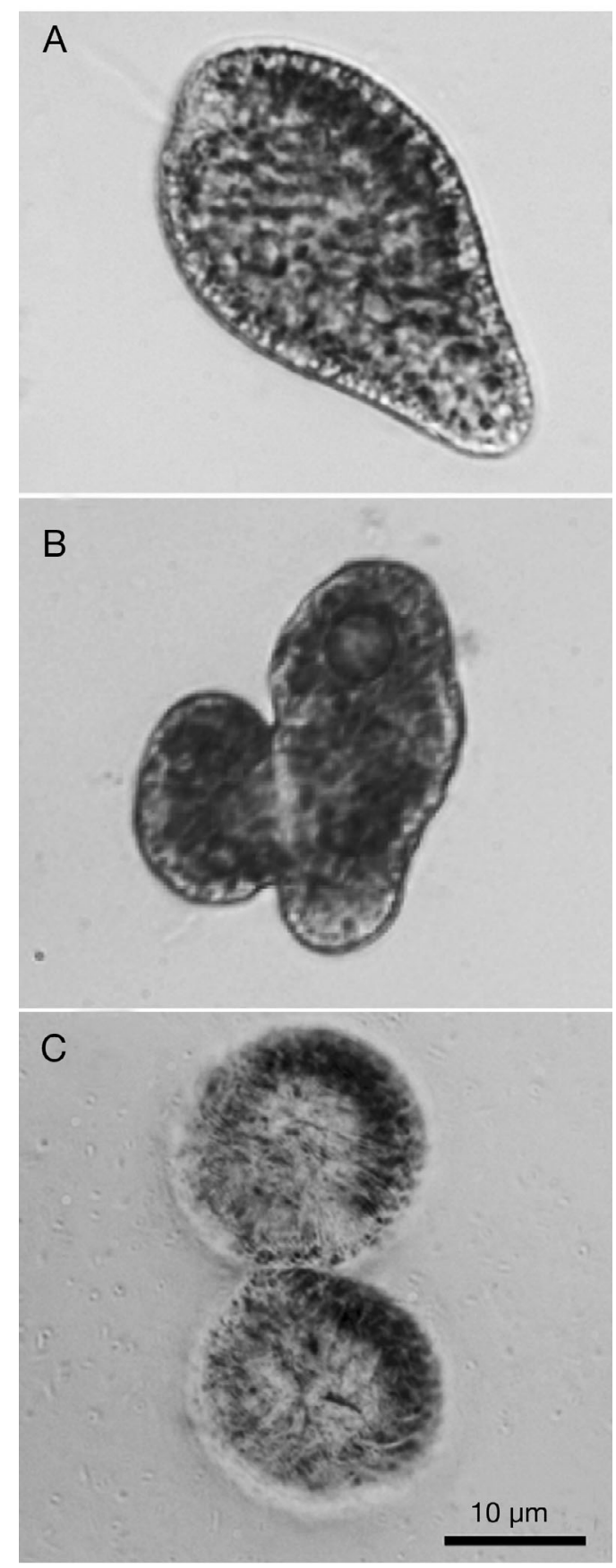

Fig. 3. Chattonella marina. Morphological change induced in C. marina after treatment with PG-L-1 $\left(10 \mu \mathrm{g} \mathrm{ml}^{-1}\right)$ for $24 \mathrm{~h}$. (A) Normal C. marina celli (B) PG-L-1-treated C. marina cells; (C) normal cells during cell division cells (Fig. 3A). The morphologically changed cells were also observed at even lower concentrations $(0.1$ and $1 \mu \mathrm{g} \mathrm{ml}^{-1}$; data not shown). In addition, the same kind of morphological changes were observed with the addition of the bacterial cell suspension but not with the addition of the washed bacterial cells (data not shown). These dimeric cells (Fig. 3B) may be attributed to the depression of cell division by PG-L-1. For comparison, normal cell division is shown in Fig. 3C. Although a few surviving C. marina cells that exhibited morphological changes were still swimming, their moving speed was abnormally decreased.

\section{Kinetic analysis of algicidal activity of PG-L-1 against Chattonella marina}

As shown in Fig. 4A, PG-L-1 had algicidal activity against Chattonella marina in a time-dependent manner. Almost all cells of $C$. marina were destroyed within $1 \mathrm{~h}$ in the presence of $100 \mu \mathrm{g} \mathrm{ml}^{-1}$ of PG-L-1. A gradual decrease in the viability of $C$. marina was observed at $10 \mu \mathrm{g} \mathrm{ml}^{-1}$ of PG-L-1, but no significant algicidal activity of PG-L-1 was shown at less than $1 \mu \mathrm{g}$ $\mathrm{ml}^{-1}$ after $6 \mathrm{~h}$ of incubation. During the longer incubation time (1 to $5 \mathrm{~d}$ ), cytostatic activity of PG-L-1 against C. marina was observed even at $0.1 \mu \mathrm{g} \mathrm{ml}^{-1}$, and the increase in viable cell counts was completely suppressed in the presence of $1 \mu \mathrm{g} \mathrm{ml}^{-1}$ of PG-L-1 (Fig. 4B).

\section{Effect of PG-L-1 on ROS production by Chattonella marina}

Chattonella marina produces ROS under normal growth conditions without the addition of exogenous stimuli, suggesting that ROS production by C. marina is essential for its growth (Oda et al. 1995). Furthermore, we found in past studies that PG-L-1 had an inhibitory effect on ROS production by phorbol myristate acetate-stimulated inflammatory cell lines (Nakashima et al. 2005b,c). Therefore, we examined the inhibitory effect of PG-L-1 on ROS production by C. marina. As shown in Fig. $5 \mathrm{~A}$, the relationship between the cell number of $C$. marina and the chemiluminescence intensity that represented the ROS level showed good linearity $\left(R^{2}=0.9519\right)$. The ROS production by $C$. marina was significantly reduced by the addition of SOD (10 U) $(\mathrm{p}<0.01$, Fig. 5B). In the SOD-inhibitable reduction system, PG-L-1 inhibited ROS production by C. marina in a concentration-dependent manner (Fig. 5B). In the presence of $10 \mathrm{\mu g} \mathrm{ml}^{-1}$ of PG-L-1, the chemiluminescence level by ROS was decreased to less than $50 \%$ of the control level. 

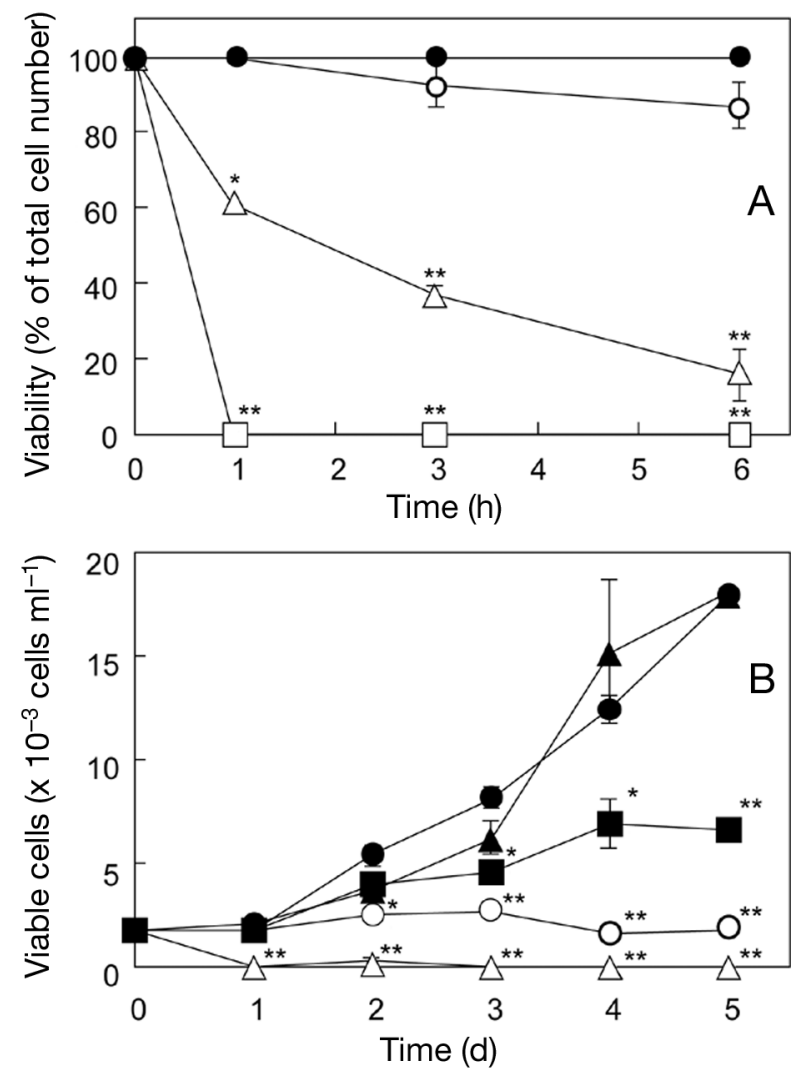

Fig. 4. Chattonella marina. Time-dependent algicidal activity of PG-L-1. (A) In short-term exposure experiments (0 to $6 \mathrm{~h}$ ), final concentrations of $0 \mu \mathrm{g} \mathrm{ml}^{-1}(\bullet), 1 \mu \mathrm{g} \mathrm{ml}^{-1}(\mathrm{O}), 10 \mu \mathrm{g} \mathrm{ml}^{-1}$ $(\triangle)$, and $100 \mu \mathrm{g} \mathrm{ml}^{-1}(\square)$ of PG-L-1 were added to C. marina cell suspensions $\left(1 \times 10^{4}\right.$ cells $\left.\mathrm{ml}^{-1}\right)$. After incubation for the indicated periods of time, the number of viable cells of $C$. marina were counted. (B) In the long-term exposure experiments ( 0 to $5 \mathrm{~d}$ ), final concentrations of $0 \mu \mathrm{g} \mathrm{ml}^{-1}(\mathbf{\bullet}), 0.01 \mu \mathrm{g} \mathrm{ml}^{-1}$

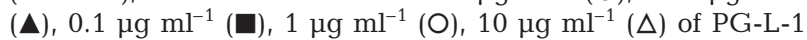
were added to $C$. marina cell suspensions $\left(1 \times 10^{3} \mathrm{cells} \mathrm{ml}^{-1}\right)$. After incubation for the indicated periods of time, the number of viable cells of $C$. marina were counted. Experiments were performed in triplicate. Error bars represent SD. Significant differences between the groups with and without PG-L-1 are indicated by *: p $<0.05 ; * *$ p $<0.01$

\section{DISCUSSION}

Over the past few decades, HABs have tended to increase worldwide, which may be correlated partly with the deterioration of marine environments and global warming. The red tide events often lead to acute shellfish poisonings or mass mortalities of aquatic organisms (Friedman \& Levin 2005). In Japan, red tide blooms, especially those due to Chattonella spp., have repeatedly caused fish mortalities (Yamamoto 2003). Therefore, control of red tide organisms or mitigation of the HABs impact is now one of the most important concerns forthe management of marine

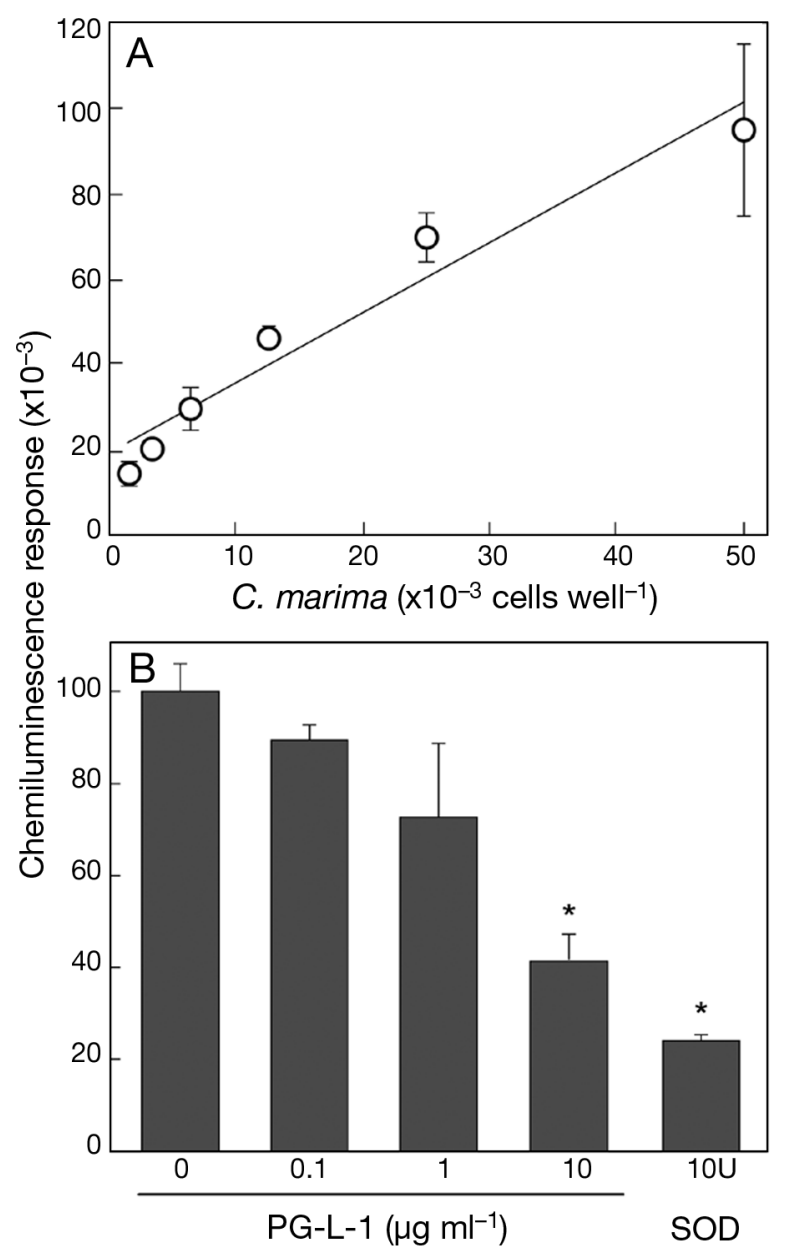

Fig. 5. Chattonella marina. Inhibitory effect of PG-L-1 on ROS production. (A) Relationship between the number of C. marina cells and chemiluminescence intensity. Various concentrations of $C$. marina were inoculated into each well of a 96-well white microplate. After the addition of chemiluminescence probe L-012 $(10 \mu \mathrm{M})$ to each well, chemiluminescence intensity was measured immediately during the initial $2 \mathrm{~min}$ as described in 'Materials and methods'. (B) Various concentrations of PG-L-1 (0 to $\left.10 \mu \mathrm{g} \mathrm{ml}^{-1}\right)$ or SOD $\left(10 \mathrm{U} \mathrm{ml}^{-1}\right)$ were added to $C$. marina cell suspensions $\left(5 \times 10^{4}\right.$ cells well $\left.^{-1}\right)$ in each well of a 96 -well white microplate. Value of the control was taken as $100 \%$, and the data represented percent of the ratio of the values in the presence of PG-L-1 or SOD. Experiments were performed in triplicate. Significant differences between the groups with and without PG-L-1 or SOD are indicated by *: $p<0.01$

environments. Based on recently accumulating knowledge of the microbial community in natural marine environments (Imai et al. 2001, Iwata et al. 2004), applications of naturally occurring algicidal bacteria and viruses have been proposed as an effective and practicable strategy for the control of HABs. Several researchers have focused on isolation and characterization of bacteria with algicidal or growth inhibitory 
activities against red tide phytoplankton. Thus, several bacteria capable of inhibiting the growth of certain phytoplanktons have been isolated from natural marine environments (Furuki \& Kobayashi 1991, Fukami et al. 1992, Imai et al. 1993, Lovejoy et al. 1998, Seong-Yun et al. 2003, Iwata et al. 2004).

A number of bacteria with algicidal activities belong to the class of gammaproteobacteria and include Pseudoalteromonas sp., Alteromonas sp., Shewanella sp. and Pseudomonas aeruginosa (Lovejoy et al. 1998, Lee et al. 2000, Hare et al. 2005, Wang et al. 2005). Since the algicidal effects were detected in the cellfree culture supernatants of some of these bacteria, researchers have suggested that some marine bacteria, e.g. Pseudoalteromonas sp. strain Y, Pseudomonas sp. strain T827/2B, and Flavobacterium sp. strain 5N-3, indirectly attack red tide phytoplankton (Baker \& Herson 1978, Fukami et al. 1992, Lovejoy et al. 1998). Pseudoalteromonas sp. strain Y (Lovejoy et al. 1998) and Pseudomonas sp. strain T827/2B (Baker \& Herson 1978) killed the microalgae through heat-labile bacterial metabolic compounds having relatively high molecular weight. Flavobacterium sp. strain $5 \mathrm{~N}-3$ produced an algicidal compound with a low molecular weight $(<500 \mathrm{Da})$ against the dinoflagellate Gymnodinium nagasakiense (Fukami et al. 1992). Nevertheless, few of these compounds have been identified, and the algicidal mechanisms are still unclear.

We found that strain MS-02-063 isolated from the coastal area of Omura Bay, Nagasaki, Japan had potent algicidal activity against Chattonella marina. However, the algicidal activity of bacterial cells washed with the planktonic medium was significantly reduced. Therefore, we concluded that extracellular substances produced by this bacterium are responsible for the algicidal activity, rather than strain MS-02-063 having an algicidal effect on $C$. marina through direct cell-to-cell contact. A biological characteristic of strain MS-02-063 is that this bacterium produces a large amount of a prodigiosin analogue, PG-L-1, as a secondary metabolic substance. The amount of the pigment produced by strain MS02-063 in YPG broth was approximately $1.1 \mathrm{mg} \mathrm{ml}^{-1}$ after incubation for $48 \mathrm{~h}$ at $28^{\circ} \mathrm{C}$ (Nakashima et al. 2005b). Nakashima et al. (2006) showed that a cell density of $>10^{5}$ cells $\mathrm{ml}^{-1}$ was required to produce the pigment, suggesting that PG-L-1 produced by strain MS-02-063 is controlled by homoserine lactone quorum sensing. In that study, when this bacterium was treated with erythromycin, the red pigment production was inhibited and the algicidal activity against Heterosigma akashiwo was completely lost. Therefore, the results of this study together with those previous findings suggest that PG-L-1 is the main algicidal compound.
The pigment PG-L-1 had potent algicidal activity against Chattonella marina in a concentrationdependent manner, and almost all cells of C. marina were readily destroyed at $100 \mu \mathrm{g} \mathrm{ml}^{-1}$. At concentrations around the $\mathrm{LD}_{50}$ values, PG-L-1 induced a characteristic morphological change in $C$. marina that seemed to inhibit cell division in C. marina. At low concentration ranges $\left(0.1\right.$ to $\left.1.0 \mu \mathrm{g} \mathrm{ml}^{-1}\right)$, PG-L-1 showed static growth-inhibitory activity against $C$. marina. The increase in the number of viable cells of $C$. marina was completely prevented in the presence of $1 \mu \mathrm{g} \mathrm{ml}^{-1}$ of PG-L-1 during the $5 \mathrm{~d}$ of incubation. These results suggested that the underlying toxic actions differ with concentrations of PG-L-1. Since PG-L-1 is hydrophobic, the prompt action of PG-L-1 at a high concentration may be attributed to the hydrophobic interaction between PG-L-1 and the cell membrane of C. marina. At low concentrations, PG-L-1 may suppress certain specific intracellular metabolic pathways in C. marina, resulting in the inhibition of cell division.

In our previous study, PG-L-1 showed potent cytotoxic activities against various cultured mammalian cell lines. We suggested that the cytotoxic mechanism of PG-L-1 is the induction of apoptotic cell death through activation of p38 mitogen-activated protein kinase in human myeloid leukemia (U937) cells (Nakashima et al. 2005c). Since PG-L-1 showed cytostatic activity against Chattonella marina, the cytotoxic mechanism of action of PG-L-1 against this raphidophyte may be different from that of mammalian cells.

Oda et al. 1998 showed that Chattonella. marina produced ROS such as superoxide anions, hydrogen peroxide, and hydroxyl radicals under normal growth conditions without specific triggers or stimuli. Although the biological significance of ROS production in $C$. marina is still unclear, it has been suggested that ROS produced by $C$. marina play essential roles as autocrine growth factors or as mitogenic stimuli in its own survival (Oda et al. 1995). During the course of searching for new aspects of biological activity of PGL-1, we found that PG-L-1 potently inhibited ROS production by phorbol myristate acetate-stimulated mouse macrophage and human myeloid leukemia cell lines (Nakashima et al. 2005b,c). Similarly, sublethal concentration of PG-L-1 inhibited ROS production by C. marina. Although the underlying mechanisms of the inhibitory activity of PG-L-1 against C. marina are still unclear, these results together with previous findings suggest that cytostatic activity of PG-L-1 against $C$. marina may be caused, at least in part, by the inhibitory effect of PG-L-1 on ROS production by this raphidophyte. It was proposed that the ROS-producing system of $C$. marina is similar to NADPH oxidase, which is present in the plasma membrane of mammalian phagocytic cells (Kim et al. 2000). In prelimi- 
nary studies, PG-L-1 led to the suppression of activation of NADPH oxidase in a macrophage cell line (data not shown). In addition, since no scavenging effect of PG-L-1 on ROS produced by hypoxanthine/xanthine oxidase system was observed (Nakashima et al. 2005c), PG-L-1 may directly act on NADPH oxidaselike enzyme in $C$. marina. Detailed analyses of the effects of PG-L-1 on both NADPH oxidase in C. marina and macrophage cell lines are now in progress.

Dinoflagellates such as Cochlodinium polykrikoides (Landsberg 2002) and Karenia (formerly Gymnodinium) mikimotoi (Yamasaki et al. 2004) are also known to produce ROS. Thus, it seems that ROS production by marine phytoplankton is not a rare phenomenon. In fact, PG-L-1 showed potent algicidal activity against these dinoflagellates (Nakashima et al. 2006). In addition, it has been reported that phlorotannins, which are antioxidants, isolated from the brown alga Eisenia bicyclis showed algicidal effect on dinoflagellates such as C. polykrikoides and G. mikimotoi (Nakamura et al. 1996, Nagayama et al. 2003). These findings suggest a possibility that scavenging or elimination of ROS lead to the inhibition of the growth of certain algal species, especially ROS-producing phytoplankton.

In conclusion, PG-L-1 may not only be a promising candidate for control of HABs, but also a useful experimental tool to analyse the biological mechanisms of ROS production. In addition, strain MS-02-063, as well as other algicidal bacteria, may play an important role in regulating microalgal biomass in natural marine environments.

Acknowledgements. This study was supported by Nagasaki Prefecture Collaboration of Regional Entities for Advancement of Technological Excellence and Japan Science and Technology Agency.

\section{LITERATURE CITED}

Baker KH, Herson DS (1978) Interactions between the diatom Thallasiosira pseudonanna [sic] and an associated pseudomonad in a mariculture system. Appl Environ Microbiol 35:791-796

Friedman MA, Levin BE (2005) Neurobehavioral effects of harmful algal bloom (HAB) toxins: a critical review. J Int Neuropsychol Soc 11:331-338

Fukami K, Yuzawa A, Nishijima T, Hata Y (1992) Isolation and properties of a bacterium inhibiting the growth of Gymnodinium nagasakiense. Nippon Suisan Gakkaishi 58: 1073-1077

Furuki M, Kobayashi M (1991) Interaction between Chattonella and bacteria and prevention of this red tide. Mar Pollut Bull 23:189-193

Hare CE, Demir E, Coyne KJ, Cary SC, Kirchman DL, Hutchins DA (2005) A bacterium that inhibits the growth of Pfiesteria piscicida and other dinophytoplankton. Harmful Algae 4:221-234
Imada I, Sato EF, Miyamoto M, Ichimori Y, Minamiyama Y, Konaka R, Inoue M (1999) Analysis of reactive oxygen species generated by neutrophils using a chemiluminescence probe L-012. Anal Biochem 271:53-58

Imai I, Ishida Y, Hata Y (1993) Killing of marine phytoplankton by gliding bacterium Cytophaga sp., isolated from the coastal Sea of Japan. Mar Biol 116:527-532

Imai I, Sunahara T, Nishikawa T, Hori Y, Kondo R, Hiroishi S (2001) Fluctuations of the red tide algae Chattonella spp. (Raphidophyceae) and the algicidal bacterium Cytophaga sp. in the seto. Inland Sea. Mar Biol 138:1043-1049

Iwata Y, Sugahara I, Kimura T, Kowa H, Matsumoto A, Noritake K (2004) Properties of an algicidal bacterium (Flavobacterium sp.) against Karenia mikimotoi isolated from Ise Bay, Japan. Nippon Suisan Gakkaishi 70:537-541

Kim D, Nakamura A, Okamoto T, Komatsu N, Oda T, Iida T, Ishimatsu A, Muramatsu T (2000) Mechanism of superoxide anion generation in the toxic red tide phytoplankton Chattonella marina: possible involvement of $\mathrm{NAD}(\mathrm{P}) \mathrm{H}$ oxidase. Biochim Biophys Acta 1524:220-227

Landsberg JH (2002) The effects of harmful algal blooms on aquatic organisms. Rev Fish Sci 10(2):113-390

Lee SO, Kato J, Takiguchi N, Kuroda A, Ikeda T, Mitsutani A, Ohtake H (2000) Involvement of an extracellular protease in algicidal activity of the marine bacterium Pseudoalteromonas sp. strain A28. Appl Environ Microbiol 66: 4334-4339

Lovejoy C, Bowman JP, Hallegraeff GM (1998) Algicidal effects of a novel marine Pseudoalteromonas isolate (class Proteobacteria, gamma subdivision) on harmful algal bloom species of the genera Chattonella, Gymnodinium, and Heterosigma. Appl Environ Microbiol 64:2806-2813

Nagayama K, Shibata T, Fujimoto K, Honjo T, Nakamura T (2003) Algicidal effect of phlorotannins from the brown alga Ecklonia kurome on red tide phytophytoplankton. Aquaculture 218:601-611

Nakamura T, Nagayama K, Uchida K, Tanaka R (1996) Antioxidant activity of phlorotannins isolated from the brown alga Eisenia bicyclis. Fish Sci 62:923-926

Nakashima T, Kato Y, Yamaguchi K, Oda T (2005a) Evaluation of antifungal activity of prodigiosin-analogue produced by $\gamma$-proteobacterium using stratum corneum epidermal of Yukatan micropig. J Infect Chemother 11:123-128

Nakashima T, Kurachi M, Kato Y, Yamaguchi K, Oda T (2005b) Characterization of bacterium isolated from the sediment at coastal area of Omura Bay in Japan and several biological activities of pigment produced by this isolate. Microbiol Immunol 49:407-415

Nakashima T, Tamura T, Kurachi M, Yamaguchi K, Oda T (2005c) Apoptosis-mediated cytotoxicity of prodigiosinlike red pigment produced by $\gamma$-proteobacterium and its multiple bioactivities. Biol Pharm Bull 28:2289-2295

Nakashima T, Matsuyama Y, Muraoka W, Yamaguchi Y, Oda T (2006) Producing mechanism of an algicidal compound against red tide phytoplankton in a marine bacterium $\gamma$-proteobacterium. Appl Microbiol Biotechnol 73(3): $684-690$

Oda T, Moritomi J, Kawano I, Hamaguchi S, Ishimatsu A, Muramatsu T (1995) Catalase- and superoxide dismutaseinduced morphological changes and growth inhibition in the red tide phytoplankton Chattonella marina. Biosci Biotechnol Biochem 59:2044-2048

Oda T, Nakamura A, Okamoto T, Muramatsu T (1998) Lectininduced enhancement of superoxide anion production by red tide phytoplankton. Mar Biol 131:383-390

Porter KG, Feig YS (1980) The use of DAPI for identifying and counting aquatic microflora. Limnol Oceanogr 25:943-948 
Sawabe T, Makino H, Tatsumi M, Nakano K and 5 others (1998) Pseudoalteromonas bacteriolytica sp. nov., a marine bacterium that is the causative agent of red spot disease of Laminaria japonica. Int J Syst Bacteriol 48:769-774

Seong-Yun J, Ishida K, Ito Y, Okada S, Murakami M (2003) Bacillamide, a novel algicide from the marine bacterium, Bacillus sp. SY-1, against the harmful dinophytoplankton, Cochlodinium polykrikoides. Tetrahedron Lett 44: 8005-8007

Shieh WY, Chen YW, Chaw SM, Chiu HH. (2003) Vibrio ruber sp. nov., a red, facultatively anaerobic, marine bacterium

Editorial responsibility: Hugh MacIntyre,

Dauphin Island, Alabama, USA isolated from sea water. Int J Syst Evol Microbiol 53: $479-484$

Wang X, Gong L, Liang S, Han X, Zhu C, Li Y (2005) Algicidal activity of rhamnolipid biosurfactants produced by Pseudomonas aeruginosa. Harmful Algae 4:433-443

Yamamoto T (2003) The Seto Inland Sea-eutrophic or oligotrophic? Mar Pollut Bull 47:37-42

Yamasaki Y, Kim DI, Matsuyama Y, Oda T, Honjo T (2004) Production of superoxide anion and hydrogen peroxide by the red tide dinophytoplankton Karenia mikimotoi. J Biosci Bioeng 97:212-215

Submitted: June 30, 2006; Accepted: September 29, 2006 Proofs received from author(s): December 19, 2006 